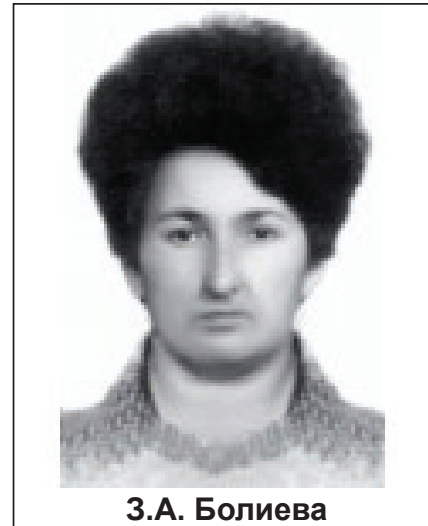

3.А. Болиева

DOI 10.23671 NNC УДК 635.21

\title{
ГИБРИДЫ КАРТОФЕЛЯ СЕЛЕКЦИИ ГОРСКОГО ГАУ (РСО-А) С УЧАСТИЕМ В РОДОСЛОВНОЙ ДИКИХ ВИДОВ
}

\section{3.А. Болиева}

Аннотация. Успех селекции зависит главным образом от верного подхода к выбору родительской пары, которая обеспечит формирование сеянцев с комплементарно-ценными признаками, однако в процессе получения гибридного потомства большинство сеянцев при отборе бракуется из-за низкого урожая, а также по различным морфобиологическим признакам, не отвечающим требованиям выхода высококачественного исходного материала для создания сорта. В связи с перспективностью использования сортов, содержащих в родословной гены диких видов, для получения гибридного потомства, устойчивого к грибным, вирусным болезням, жаре и засухе, нами проведены скрещивания в 2011 году в экологических условиях горной зоны РСО-А (с. Горный Куртат Алагирского района, 1400 м н. у. м).

Ключевые слова: селекция, картофель, гибриды, сорт, ген.

Технология выращивания гибридного потомства проводилась в соответствии с методикой исследования по культуре картофеля. В процессе гибридизации было получено гетерозиготное потомство различных фрорм картофреля в количестве 84, с участием в родословной родительских пар генов диких видов S. demissum, S. stoloniferum, S. andigenum, $S$ chacoense, S. microdontum, S. acaule, S. leptostigma, S. sparcipillum, S. bulbocastanum, S. sucrense, S. phureja.

Из них выделено 12 гибридов разных комбинаций, сфрормировавших урожай от 51 т/га до 56,4 т/га. Гибриды 11.26/215, 11.26/241, 11.26/782, 11.26/35, 11.35/127, 11.30/1 будут в 2018 г. проходить лабораторное испытание 1-го года по раку и золотистой картофельной нематоде.

В области биологии и биохимии в настоящее время происходит удивительный процесс, который захватил и селекцию. Этот процесс применителен к немногим культурам, в том числе и к картофелю, т. к. последний обладает высокой пластичностью. Картофель - тетраплоид, его можно вегетативно размножить, регенерировать из тканей и протопластов, подвергать трансформации и среди объектов селекции именно к нему больше всего применимы все новые результаты исследований, следовательно, без тесного сотрудничества и быстрой передачи научных результатов в практику прогресс невозможен. Но современная интенсификация сельского хозяйства, а также глобальные изменения агроклиматических условий зон выращивания картофеля перед селекционерами поставили проблемную задачу получения сортов с высоким качеством клубня $[1,11,18]$.

В настоящее время мы имеем множество эффрективных результатов исследований, фракторов, которые подтверждают новые высокозначимые достижения по повышению качества полученной продукции и урожайности в процессе гибридизации. На сегодняшний день гибридное потомство выращивается на больших площадях в различных крестьянско-фрермерских хозяйствах и научных организациях, на опытных площадях Северо-Кавказского региона; оно получено путем скрещивания родительских форм, отличающихся не только по морфологическим, хозяйственно-ценным признакам, но и отдаленностью родственных отношений между родительскими парами.

Следует отметить, что современное производство высококачественных коммерческих сортов, созданных на основе использования в скрещиваниях двух - трех диких и культурных видов рода Solanum, содержащих гены устойчивости к агрессивным возбудителям не только вирусных, но и грибных болезней, приобретает все большую популярность.

Гибридное потомство от таких родительских пар отличается мощным первоначальным развитием с ярко выраженным габитусом куста и более продуктивным по сравнению с родителями. Эти параметры учитываются при проведении отборов генотипов по методике, включающей до 52 хозяйственно-ценных признаков.

Эффрективные результаты получены в области биотехнологии по оздоровлению гибридного потомства картофеля через in vitro и технологический процесс аэрогидропоники, что имеет большое значение в семеноводстве свободного от вирусной инфекции картофеля для южных регионов России.

Многолетними исследованиями доказано, что успех селекции главным образом зависит от правильного выбора родительской пары, которая даст в потомстве сеянцы с комплементарно-ценными признаками. Но в процессе получения гибридного потомства большинство сеянцев бракуется из-за низкой продуктивности с одного куста, а следовательно, и малого урожая. Это приводит к выводу, что следует подбирать таких родителей, которые дадут гетерозиготное потомство, в котором отобраны генотипы с более высоким качеством хозяйственно-ценных признаков [3, 16, 17].

В связи с эфффективностью и перспективностью 
Происхождение гибридного потомства селекции ФГБОУ ВО

Таблица 1

Горский ГАУ, горная зона РСО-Алания, 2015-2017 г.

\begin{tabular}{|c|c|c|c|c|c|c|c|}
\hline \multirow{2}{*}{ Гибрид } & \multirow{2}{*}{$\begin{array}{c}\text { Происхож- } \\
\text { дение }\end{array}$} & \multirow{2}{*}{$\begin{array}{c}\text { Дикие виды в родо- } \\
\text { словной родитель- } \\
\text { ской пары }\end{array}$} & \multirow{2}{*}{$\begin{array}{c}\text { Устойчи- } \\
\text { вость к } \\
\text { тяжелым } \\
\text { формам } \\
\text { вирусных } \\
\text { болезней, } \\
\text { балл } \\
\end{array}$} & \multicolumn{2}{|c|}{$\begin{array}{c}\text { Устойчивость к } \\
\text { фитофторе, } \\
\text { балл }\end{array}$} & \multicolumn{2}{|c|}{$\begin{array}{l}\text { Потемнение } \\
\text { мякоти, балл }\end{array}$} \\
\hline & & & & ботве & $\begin{array}{c}\text { клуб- } \\
\text { ням }\end{array}$ & $\begin{array}{l}\text { сы- } \\
\text { ром } \\
\text { виде }\end{array}$ & $\begin{array}{l}\text { варе- } \\
\text { ном- } \\
\text { виде }\end{array}$ \\
\hline $11.26 / 782$ & $\begin{array}{l}87.759-3 \times \\
\text { Резерв }\end{array}$ & $\begin{array}{l}\text { S.demissum } \\
\text { S.stoloniferum } \\
\text { S.andigenumvarBolti } \\
\text { vianum }\end{array}$ & 5 & 8 & 8 & 9 & 3 \\
\hline $11.26 / 816$ & $\begin{array}{l}87.759-3 \\
\times \text { Резерв }\end{array}$ & $\begin{array}{l}\text { S. demissum } \\
\text { S. stoloniferum } \\
\text { S. andigenumvarBol- } \\
\text { tivianum }\end{array}$ & 7 & 8 & 9 & 9 & 3 \\
\hline $11.26 / 35$ & $\begin{array}{l}87.759-3 \times \\
\text { Резерв }\end{array}$ & $\begin{array}{l}\text { S. demissum } \\
\text { S. stoloniferum } \\
\text { S. andigenumvarBol- } \\
\text { tivianum }\end{array}$ & 5 & 9 & 9 & 9 & 2 \\
\hline $11.26 / 475$ & $\begin{array}{l}87.759-3 \times \\
\text { Резерв }\end{array}$ & $\begin{array}{l}\text { S. demissum } \\
\text { S. stoloniferum } \\
\text { S. andigenumvarBol- } \\
\text { tivianum }\end{array}$ & 7 & 9 & 7 & 9 & 2 \\
\hline $11.26 / 470$ & $\begin{array}{l}87.759-3 \times \\
\text { Резерв }\end{array}$ & $\begin{array}{l}\text { S. demissum } \\
\text { S. stoloniferum } \\
\text { S. andigenumvarBol- } \\
\text { tivianum }\end{array}$ & 7 & 9 & 9 & 8 & 3 \\
\hline $11.26 / 215$ & $\begin{array}{l}87.759-3 \times \\
\text { Резерв }\end{array}$ & $\begin{array}{l}\text { S. demissum } \\
\text { S. stoloniferum } \\
\text { S. andigenumvarBol- } \\
\text { tivianum }\end{array}$ & 7 & 8 & 9 & 8 & 3 \\
\hline $11.26 / 241$ & $\begin{array}{l}87.759-3 \times \\
\text { Резерв }\end{array}$ & $\begin{array}{l}\text { S. demissum } \\
\text { S. stoloniferum } \\
\text { S. andigenumvarBol- } \\
\text { tivianum }\end{array}$ & 7 & 9 & 9 & 8 & 2 \\
\hline $11.35 / 160$ & $\begin{array}{l}\text { Инноватор } \times \\
\text { Premjer }\end{array}$ & $\begin{array}{l}\text { S.chacoense } \\
\text { S. demissum } \\
\text { S.microdontum } \\
\text { S.acaule } \\
\text { S.andigenum } \\
\text { S.stoloniferum } \\
\end{array}$ & 7 & 9 & 9 & 9 & 3 \\
\hline $11.35 / 8$ & $\begin{array}{l}\text { Инноватор } \times \\
\text { Premjer }\end{array}$ & $\begin{array}{l}\text { S. chacoense } \\
\text { S. demissum } \\
\text { S. microdontum } \\
\text { S. acaule } \\
\text { S. andigenum } \\
\text { S. stoloniferum }\end{array}$ & 7 & 9 & 9 & 9 & 2 \\
\hline $11.35 / 127$ & $\begin{array}{l}\text { Инноватор } \times \\
\text { Premjer }\end{array}$ & $\begin{array}{l}\text { S. chacoense } \\
\text { S. demissum } \\
\text { S. microdontum } \\
\text { S. acaule } \\
\text { S. andigenum } \\
\text { S. stoloniferum }\end{array}$ & 7 & 9 & 9 & 9 & 2 \\
\hline $11.30 / 1$ & $\begin{array}{l}\text { Предгор- } \\
\text { ный } \\
\text { ×Libana }\end{array}$ & $\begin{array}{l}\text { S.tuberosum } \\
\text { S.demissum } \\
\text { S.microdontum } \\
\text { S.demissum }\end{array}$ & 7 & 8 & 9 & 8 & 2 \\
\hline
\end{tabular}


Продуктивность гибридного потомства родительской пары, г/куст

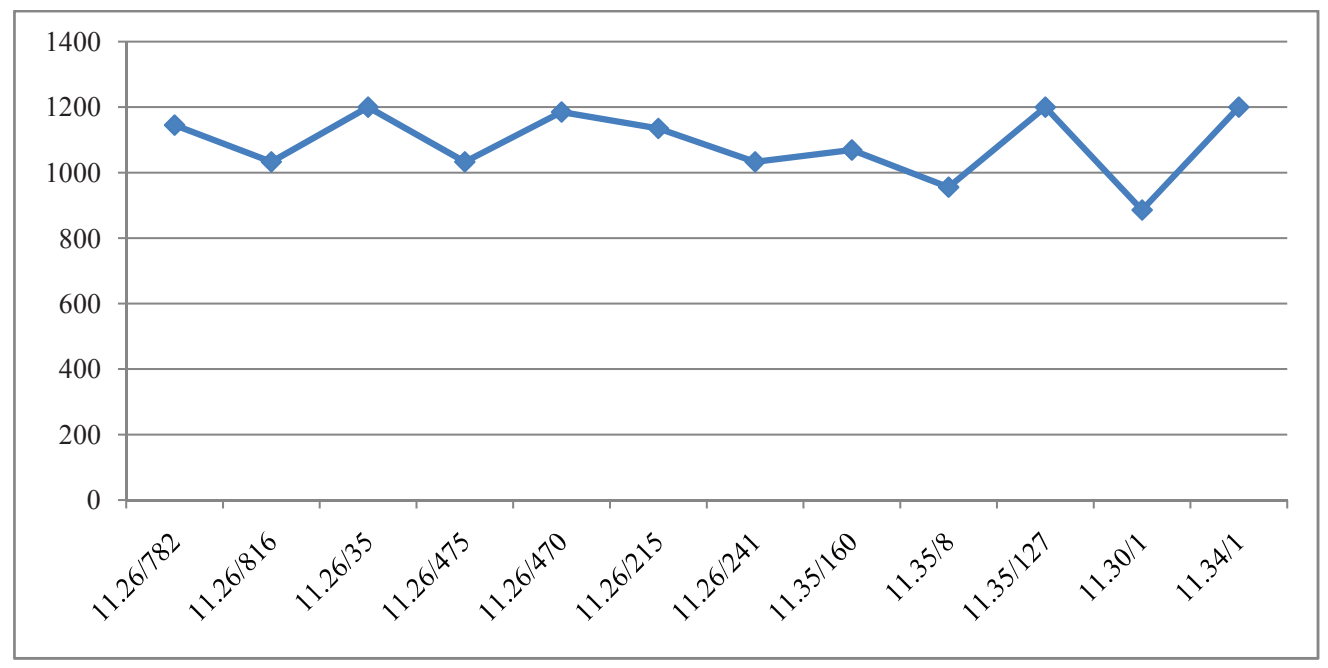

использования сортов, содержащих в родословном гены диких видов для создания гибридного потомства, устойчивого к вирусным, грибным болезням, нами были проведены скрещивания в 2011-2014 гг. в условиях горной зоны (с. Горный Куртат, 1400 м н. у. м). Почвы экспериментального участка горнолуговые, дерновые, слабокислые $-\mathrm{pH}=4,9-5,2$. Содержание гумуса в верхнем горизонте 5-6 \%, в горизонте В - 3 \% [4]. Годовое количество осадков 540 мм, а за вегетацию выпадает 460 мм. Многолетняя суточная температура воздуха $+5,9{ }^{\circ} \mathrm{C}$. Сумма температур за вегетацию $1800-2600{ }^{\circ} \mathrm{C}$. Технология выращивания гибридного потомства была проведена в соответствии с методикой исследования по культуре картофреля [4].

Визуальное обследование на наличие вирусных болезней проводили по методике Попковой [9]. Лабораторные исследования на наличие скрытой инфекции по методике «Инструкция проведения ИФА» [10].

Результаты и их обсуждение. Основой процесса гибридизации, как было отмечено выше, является эффективный выбор родительской пары. Так, в 26-й комбинации (табл. 1) для скрещивания были использованы сорт Резерв и межвидовой гибрид $87.759 / 3$, обладающие высокой комбинационной способностью. Эта родительская форма создана на основе привлечения диких видов, содержащих гены устойчивости к вирусным и грибным болезням - S. demissum, S. stoloniferum, S. andigenumvar Boltivianum. Сорта Инноватор, Premjer, Синюха были созданы с привлечением таких диких видов, как S. chacoense, S. demissum, S. microdontum, S. acaule, S. andigenum, S. stoloniferum, S. plurja, coдержащих гены устойчивости к возбудителям тяжелых форм вирусных болезней - ВВКК, ВМКК, ВСЛК. Среднеранний сорт Предгорный и среднепоздний Libana были выведены с привлечением в скрещивание диких видов S. leptostigma, S. sparcipillum, а также S. tuberosum и других, как видно на таблице 1.
Таким образом, в результате привлечения в скрещивание родительских пар, созданных с участием в их родословной диких видов, нами было получено 10 гибридов с высоким иммунитетом устойчивости (7 баллов) к тяжелым фрормам вирусных болезней и 2 генотипа со средней устойчивостью (5 баллов).

Высокий иммунитет устойчивости к возбудителю фритофтороза (Fitoftora infestans) по ботве и клубням проявили 7 образцов по четырем комбинациям, остальные оценены баллами 8-8, 9-9.

Признак потемнения мякоти клубня картофеля является важным параметром, определяющим качество клубня, оно объясняется генетическим фактором, т. к. передается гибридному потомству в той или иной степени, следовательно, для скрещивания подбираются родительские фрормы, мякоть которых не темнеет в сыром и вареном виде. Мякоть может темнеть и при уборке (клубни повреждаются), затаривании в отсеки и контейнеры, а также за счет нарушений рекомендованных норм удобрений и соотношение элементов питания, при хранении за счет пораженности клубней болезнями, если семенной материал не обработали соответствующим препаратом.

В наших исследованиях в гибридном потомстве 7 образцов имели совершенно нетемнеющую мякоть в комбинациях 87.759-3 × Резерв, Инноватор $\times$ Premjer, родословная которых содержит гены S. stoloniferum и S. andigenumvar Boltivianum. B остальных комбинациях гибриды имели почти нетемнеющую мякоть с баллами 8-2 и 8-3.

В процессе подбора родительской пары большое значение имеет высокая продуктивность одного или обеих родителей, потому что этот показатель зависит от числа стеблей массы клубня. Число клубней генетически детерминировано числом стеблей и составляет, в среднем, в гибридном потомстве от 4-5 до 5-6. Комбинации 87.759/3 х Резерв, Инноватор х Premjer, Инноватор х Синюха сформи- 
ровали продуктивность одного куста от 1033 до 1 185 г; 963,6 до 1200 г соответственно (диаграмма 1). По остальным комбинациям продуктивность с куста гибридного потомства превышала 885,7 г.

Товарность гибридного потомства по всем комбинациям отвечает стандартным требованиям по категориям и классам как семенного, так и продовольственного картофеля, и составляет от 88,9\% у гибрида $11.26 / 475$ до 100 \% по гибриду 11.35/12. Как видно на диаграмме 2, гибриды 11.26/215,
$11.26 / 241,11.26 / 782,11.26 / 35,11.35 / 127,11.30 / 1$ накопили урожай от 51 до 56,4 т/га соответственно. Таким образом, в селекционной работе ФГБОУ Горский ГАУ в процессе гибридизации нами сфрормирован высококачественный исходный гибридный материал для дальнейшей работы по созданию сортов, отвечающих требованиям биотических и абиотических факторов зон выращивания в условиях Северо-Кавказского региона и Юга России.

Товарность и урожайность гибридного потомства

Диаграмма 2

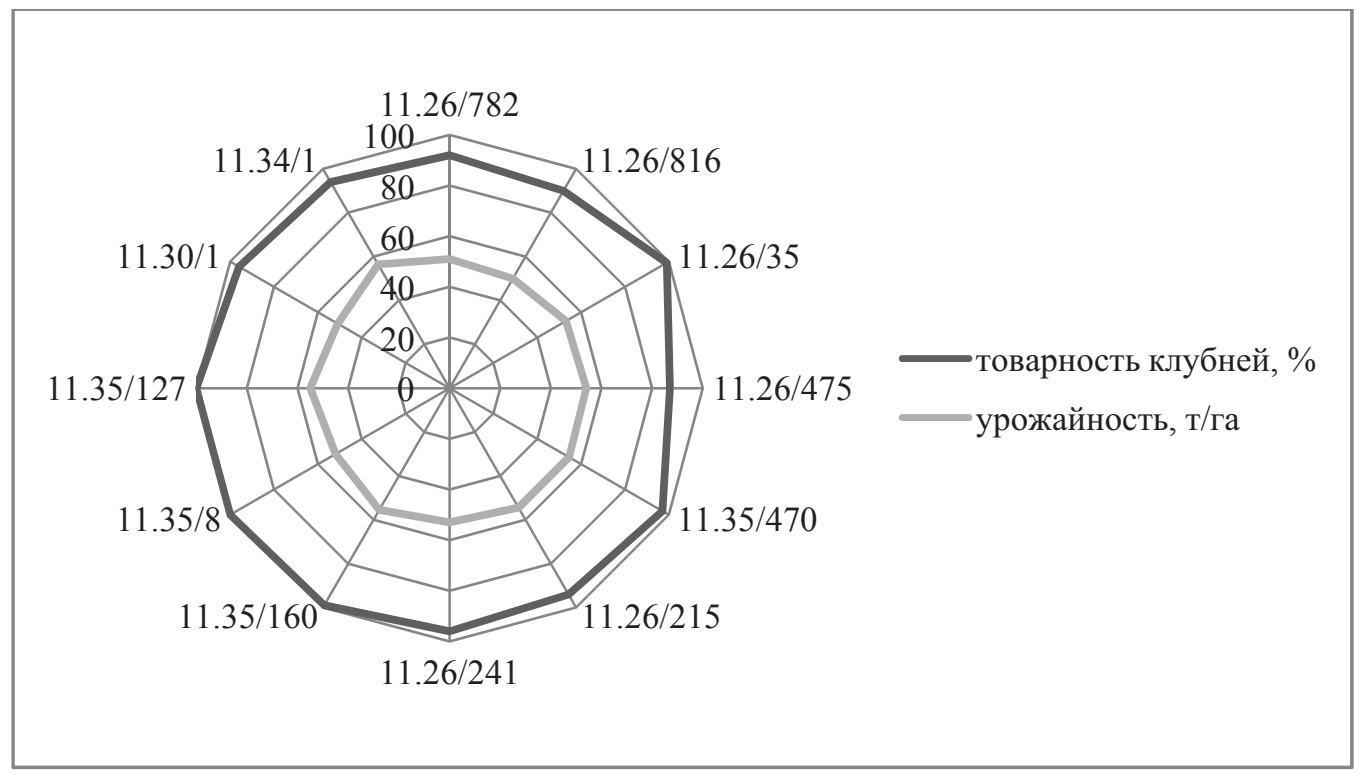

\section{ЛИТЕРАТУРА}

1. Басиев С.С. Перспективы селекции картофреля на основе моделирования новых сортов картофеля предгорий Северо-Кавказского региона / Басиев С.С., Шорин П.М., Болиева З.А., Дзгоев О.К и др. // Известия Горского государственного аграрного университета. Том 39. Части 1-2, 2012. С. 41.

2. Болиева 3.А. Значение сорта картофеля в поддержании экологического равновесия агроландшафта в условиях предгорной зоны Республики Северная Осетия-Алания / Болиева 3.А., Доева Л.Ю., Лихненко С.В. // В сборнике: Современная индустрия картофеля: состояние и перспективы развития. Материалы VI межрегиональной научно-практической конференции. 2014. С. 80-84.

3. Веселовский И.А. Введение в генетику /И.А. Веселовский. - М: Колос, 1969. С. 4.

4. Дзанагов С.X. Плодородие почв и удобрения / С.Х. Дзанагов. - Орджиникидзе: Ир, 1987. 200 с.

5. Доева Л.Ю. Конкурентоспособность отечественных сортов картофеля / Доева Л.Ю., Лихненко С.В., Болиева З.А. // В сборнике: Актуальные и новые направления в селекции и семеноводстве сельскохозяйственных культур. Материалы Международной научно-практической конфреренции, посвященной юбилею профессора Сарры Абрамовны Бекузаровой, 2017. C. 75-78.

6. Зыкин А.Г. Вирусные болезни / А.Г. Зыкин. - Л.: Колос. 1976. 152 c.

7. Козаева Д.П. Редуцирующие сахара и качество картофрелепродуктов / Козаева Д.П., Болиева З.А., Доева Л.Ю. // В сборнике: Современное состояние и перспективы развития картофрелеводства. Материалы IV научно-практической конференции, 2012. С. 239-240.
8. Методические указания по технологии селекции, 2006. C. 19-20.

9. Попкова К.В. Болезни картофреля / Попкова К.В., Шнейдер Ю.М., Воловик А.С., Шмыгля В.А. - М.: Колос, 1980. С. 3-4, 183-185, 185-187.

10. Симаков E.A. Генетические основы селекции картофреля на улучшение питательной ценности / Симаков Е.А., Яшина И.М.// Защита картофреля, 2011. № 1. С. 2-5.

11. Ханс Росс. Селекция картофреля. Проблемы и перспективы. - М.: «Агропромиздат», 1989. С. 3.

12. Щербинин А.Н. Производство экологически безопасной продукции растениеводства / Щербинин А.Н., Лихненко С.В. - Пущино, 1997. С. 60-62.

13. Щербинин А.H. Серологическая оценка с применением буфрерного раствор / Щербинин А.Н., Хамман У., Рунге, 1974-1975.

14. Ящина И.М. Модель сорта картофеля / Ящина И.М. // Плодоовощное хозяйство, 1986. № 1. С. 41-43.

15. Davidson S.Z. Some effect of leaf area control on the yield of wheat / Davidson S.Z. // Aust. S. of Agric. Research, 1965. V. 16., 5. P. 721-731.

16. Diener T.O. Raymer W.B. Potato Spindle Tuber «Virus»: A plant virus with Properties of a Free Nucleic Acid.-Repr. From Science, October. 20. 1967, vol. 158, №3799. - P. 378-381.

17. Diener T.O. Potato Spindle Tuber «Virus» / Diener, T.O. Repr. From Virologi, 1971. Vol. 45. №2.1. P. 49-58.

18. Houten J. Heat treatment and meristem culture for the production of virusfree plant material. - In: World Rev. Pest. Control, 1968.7.2. P. 115-120. 


\title{
POTATO HYBRIDS OF GGAU (MOUNTAINOUS STATE AGRARIAN UNIVERSITY OF THE REPUBLIC OF NORTH OSSETIA-ALANIA) SELECTION, CONTAINING WILD GENES IN THE PEDIGREE LINE
}

\author{
Z.A. Boliyeva \\ PhD, Gorsky State Agrarian University, Vladikavkaz. Russia.
}

Abstract. The success of breeding depends mainly on the correct approach to the choice of the parent couple, which will ensure the formation of seedlings with complementary-valuable traits, however, in the process of obtaining the hybrid progeny, the majority of seedlings are rejected due to the low yield, and also because of different morphobiological features, that do not meet the requirements of releasing high-quality raw material for the variety creation. Considering prospects of using varieties, containing wild genes in the pedigree line for acquiring hybrid progeny resistant to fungal, viral diseases, heat and drought, we carried out the crossbreeding in 2011 in the ecological conditions of the mountainous zone of the Republic of North Ossetia-Alania (Gorny Kurtat village, Alagir district, 1400 m. a. s. I.).

Keywords: breeding, potato, hybrids, grade, gene.

\section{REFERENCES}

1. Basiev, S.S. Perspektivy selektsii kartofelya na osnove modelirovaniya novykh sortov kartofelya Predgoriy Severo-Kavkazskogo regiona / Basiev S. S., Shorin P.M., Bolieva Z.A., Dzgoev O.K i dr. // Izvestiya Gorskogo Gosudarstvennogo Agrarnogo universiteta. Tom 39. Chasti 1-2, 2012. S. 41.

2. Bolieva, Z.A. Znachenie sorta kartofelya v podderzhanii ekologicheskogo ravnovesiya agrolandshafta $v$ usloviyakh predgornoy zony respubliki Severnaya Osetiya-Alaniya / Bolieva Z.A., Doeva L. Yu., Likhnenko S.V. // V sbornike: Sovremennaya industriya kartofelya: sostoyanie i perspektivy razvitiya. Materialy VI mezhregional'noy nauchno-prakticheskoy konferentsii. 2014. S. 80-84.

3. Veselovskiy, I.A. Vvedenie v genetiku /I.A. Veselovskiy. - M: Kolos, 1969. S. 4

4. Dzanagov, S.Kh. Plodorodie pochv i udobreniya / S.Kh. Dzanagov. - Ordzhinikidze: Ir, 1987. 200 s.

5. Doeva, L.Yu. Konkurentosposobnost' otechestvennykh sortov kartofelya / Doeva L.Yu., Likhnenko S.V., Bolieva Z.A. // V sbornike: Aktual'nye $i$ novye napravleniya $v$ selektsii $i$ semenovodstve sel'skokhozyaystvennykh kul'tur. Materialy Mezhdunarodnoy nauchno-prakticheskoy konferentsii, posvyashchennoy yubileyu uchenogo selektsionera, Zasluzhennogo izobretatelya RF, Zasluzhennogo deyatelya nauki RSO-Alaniya, doktora sel'skokhozyaystvennykh nauk, professora Sarry Abramovny Bekuzarovoy, 2017. S. 75-78.

6. Zykin, A.G. Virusnye bolezni / A.G. Zykin. - L.: Kolos. 1976. -152s

7. Kozaeva, D.P. Redutsiruyushchie sakhara i kachestvo kartofeleproduktov / Kozaeva D.P., Bolieva Z.A., Doeva L.Yu. // V sbornike: Sovremennoe sostoyanie i perspektivy razvitiya kartofelevodstva. Materialy IV nauchno-prakticheskoy konferentsii, 2012. S. 239-240.

8. Metodicheskie ukazaniya po tekhnologii selektsii, 2006. S. 19-20.

9. Popkova, K.V. Bolezni kartofelya / Popkova K.V., Shneyder Yu.M., Volovik A.S., Shmyglya V.A. - M.: Kolos, 1980. S. 3-4, 183-185, 185-187.

10. Simakov, E.A. Geneticheskie osnovy selektsii kartofelya na uluchshenie pitatel'noy tsennosti / Simakov E.A., Yashina I.M.// Zashchita kartofelya, 2011. №1. S. 2-5.

11. Khans Ross. Selektsiya kartofelya. Problemy i perspektivy. - M.: "Agropromizdat», 1989. S. 3.

12. Shcherbinin A. N. Proizvodstvo ekologicheski bezopasnoy produktsii rastenievodstva / Shcherbinin A N., Likhnenko S.V. - Pushchino, 1997. S. 60-62.

13. Shcherbinin A.N. Serologicheskaya otsenka s primeneniem bufernogo rastvor / Shcher-binin A.N., Khamman U., Runge, 1974-1975.

14. Yashchina, I.M. Model' sorta kartofelya / Yashchina I.M. // Plodoovoshchnoe khozyaystvo, 1986. №1. S. 41-43.

15. Davidson, S.Z. Some effect of leaf area control on the yield of wheat / Davidson S.Z. //Aust. S. of Agric. Research, 1965. V. 16., 5. P. 721-731.

16. Diener T.O., Raymer W.B. Potato Spindle Tuber «Virus»: A plant virus with Properties of a Free Nucleic Acid-Repr. From Science, October. 20. 1967, vol. 158, №3799. - P. 378-381.

17. Diener, T.O. Potato Spindle Tuber «Virus» / Diener, T.O. - Repr. From Virologi, 1971. Vol. $45 . \quad$ №2.1. P. 49-58.

18. Houten J. Heat treatment and meristem culture for the production of virusfree plant material. - In: World Rev. Pest. Control, 1968.7.2. P. 115-120. 